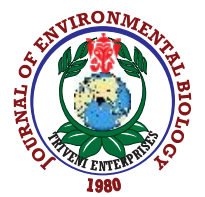

\title{
Indian Black Eagle Ictinaetus malayensis (Temminck, 1822): Observations on nesting biology in Mizoram, India
}

\author{
L. Sailo', C. Lawmsangzuala', C. Lallawmkima', C. Lalruatfela ${ }^{2}$, C. Vanlalhruaizela ${ }^{3}$, K. Lalnunthara', A. Rochamliana ${ }^{1}$ and H. \\ Lalthanzara* \\ ${ }^{1}$ Conservation Mizoram, C-95, Chanmari, Aizawl-796 007, India \\ ${ }^{2}$ Sailam Ecological Conservation Society, Sailam-796 190, India \\ ${ }^{3}$ Department of Mass Communication and Journalism, Mizoram University, Aizawl-796 005, India \\ ${ }^{4}$ Department of Zoology, Pachhunga University College, Aizawl-796 001, India \\ *Corresponding Author Email : hzara.puc@gmail.com
}

Paper received: 02.12.2019

Revised received: 25.06 .2020

Accepted: 10.07 .2020

\begin{abstract}
Aim: This study was undertaken to investigate the nesting behaviour of Indian Black Eagle Ictinaetus malayensis (Temminck, 1822).

Methodology: Observation sheets were made following Bald Eagle Monitoring Guidelines prepared for United States Fish and Wildlife Service-2007 with few modifications made to fit the necessities. Concealment nets were used to hide the observer in the observation post and other safety precautions were followed all through the monitoring process. Nikon P900, D7200, D500 fitted with a 200-500 mm lens were used for photography and Nikon Aculon A211 (15x50) binocular for observing the nest. The nest was observed for 85 days starting from early morning ( $0530 \mathrm{hrs}$ ) to evening ( $1730 \mathrm{hrs}$ ) by the observers in three shifts.

Results: The present study observed that the breeding season of $I$. malayensis begins from mid-December (aerial display) to February with the breeding pair building their nest on the branches placed horizontal to the branch of large old trees $25 \mathrm{~m}$ above the ground. The nests were 1-1.5 $\mathrm{m}$ in diameter and are lined with green leafy twig every alternate day while incubating and after each feed post-hatching. A single egg was laid and incubated for 30-35 days, young eagle need additional 50-60 days to fledge. We also observed that the diet solely consisted of rodents, especially the Pallas's Squirrel, Hoary-bellied Squirrel, snakes, lizards and rats.

Interpretation: I. malayensis, a top predator in the evergreen montane forest of Mizoram, mainly feed on rodents, thus playing a very important role in controlling the rodent population, while no instance of village fowl killed by I. malayensis was not recorded either by the authors nor the villagers themselves. The breeding success rate may not be high as only one of the two nests observed was successful, therefore, conserving this majestic forest raptor is essential for maintaining a balance of the forest ecosystem in the hill state.

Keywords: Breeding biology, Indian Black Eagle, Mizoram, Sailam

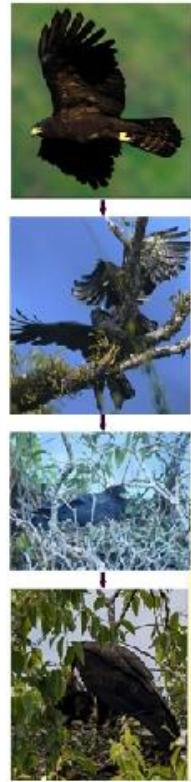
Indian Black Eagle, Ictinaetus malayensis (Temminck, 1822), a large diurnal raptor, inhabiting the montane evergreen forest, is a resident of Southeast Asia. Its breeding biology is very little known, with no literature from Mizoram and northeast India.

Two nests identified at Sailam village, Mizoram Observation sheet was prepared based on US Bald Eagle monitoring guidelines. Nesting behaviour was thorougly observed for 12 hrs a day in three shifts for 85 days.

Breeding was recorded during mid-December to late-March (aerial display \& nest building) * Nesting: $25 \mathrm{~m}$ high in an old large trees using twigs and branches, lined with green leaves ${ }^{*}$ Nest size: 1 - $1.5 \mathrm{~m}$ in diameter

* Lays single egg, incubated for 30-35 days * Feeds mainly on rodents (Pallas' squirrels) Eaglet needs 50-60 days to fledge after hatching
\end{abstract}

How to cite : Sailo, L., C. Lawmsangzuala, C. Lallawmkima, C. Lalruatfela, C. Vanlalhruaizela, K. Lalnunthara, A. Rochamliana and H. Lalthanzara: Indian Black Eagle Ictinaetus malayensis (Temminck, 1822): Observations on nesting biology in Mizoram, India. J. Environ. Biol., 41, 896-900 (2020). 


\section{Introduction}

The Indian Black Eagle, Ictinaetus malayensis (Temminck, 1822), a true forest raptor is one of the birds of prey that frequent the sky above the hill forests of Mizoram, however, observing it perched is an exceptional experience even for a great ornithologist and experienced birdwatchers, who often admiringly gaze as they slowly glide over the thick canopy of the hills and deep valleys. Henry (1933) wrote, "I have never seen it perched, and the feature of its flight that has particularly struck me is the slowness with which it can sail without any wing-flapping, even when it finds itself in a deep pocket among the trees where it would seem inevitable that it must either crash or extricate itself by flapping flight. It seems to be able to avoid stalling even at what appears little more than walking pace, and certainly at very low speed."

I. malayensis locally known as 'Lungdup' is a large diurnal raptor that inhabits mountain forests of tropical and subtropical Asia (Clark, 1994; Ferguson-Lees and Christie, 2001). It is placed under the family Accipitridae and is the only specie of the genus Ictinaetus. Two subspecies are I. m. malayensis from eastern Myanmar to southern China, through SoutheastAsia and south to Indonesia, and $I$. $m$. perniger of the Indian subcontinent and Sri Lanka have been recently recognized (Ferguson-Lees and Christie, 2001). The subspecies differ mainly in size, the nominate being larger (Stresemann and Amadon, 1979; Clark, 1994; Ferguson-Lees and Christie, 2001). I. malayensis are widespread in distribution and are not included in IUCN threatened category; however, they are rare resident of the hill forest and mountains, rather inhabited near forest edge and clearings for agricultural cultivations and secondary growth. Their population is estimated to be around 10,000 and is declining due to unending deforestation (Lepage, 2014). The species' unique character with long, broad, paddle-shaped wings and widely splayed primary tips enables the bird to glide slowly above tree level or in and out of the upper canopy, and create a highly distinctive wing shape, allowing it to be identified with ease in the field from other large raptors (Naoroji, 2006; Brazil, 2009; Rasmussen and Anderton, 2012).

The breeding biology of $I$. malayensis has been previously studied by several researchers (Soleha, 2000; Chiu and Lim, 2003; Lim and Hut, 2005; Lin, 2005; Naoroji, 2006; Lin and Lin, 2010; and Samarawickrama et al., 2011). Nest site observation was also done by Fernando et al. (2001) and Gunawardena (2002) in Sri Lanka. Information about the diet of this eagle is meagre, it is believed to prey upon large insects, lizards, rodents, birds sometimes reportedly kill junglefowl and pheasants and also mostly bird's eggs and nestlings (Ali and Ripley, 1983), Indian Giant Squirrel (Borges, 1986) and also nestling field mice, bats and cave Swiftlets (Collocalia spp.) have been recorded as food items (Robert, 1991). To date, there has been no literature on the I. malayensis from Mizoram. The record of sightings from the hill state is merely an inclusion of birds from some protected area in few checklists (Sailo et al., 2013; Lalthanzara et al., 2015) and no detailed studies have been carried out on this species. In the light of the above, this study was carried out to investigate breeding biology observation to provide baseline data on the ecology of this magnificent raptor. To our knowledge, this is the first report from the region. With reports compiled from two breeding season and numerous observations, we present the detailed breeding biology of $I$. malayensis in Mizoram.

\section{Materials and Methods}

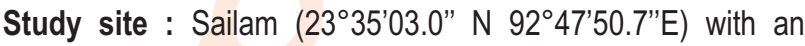
elevation of roughly $1315 \mathrm{~m}-1448 \mathrm{~m}$ is located approximately $100 \mathrm{~km}$ south from Aizawl, the capital city of Mizoram. The population of this village was 980 according to the 2020 Village Population Census. It is situated amidst the pristine evergreen forest and is an important historical village for the Mizo as a whole.

Presently with its 172 households, Sailam village is not only an important village historically but also in terms of biodiversity, especially the avifaunal diversity. It houses the first Bird Sanctuary of the state named Sailam Bird Sanctuary. The uniqueness of this Bird Sanctuary lies in the fact that it was declared, managed and maintained by the people of the village through the activity of various Non-governmental Organizations, particularly the Sailam Ecological Conservation Society (SECS). The designated Bird Sanctuary (roughly $7 \mathrm{~km}^{2}$ ) and all the adjacent areas are conserved through community participation.

Methods : Observation sheets were made following Bald Eagle Monitoring Guidelines prepared for United States Fish and Wildlife Service-2007 (downloaded from https://www.fws. gov>pdf), although few modifications were made to fit the necessities. Concealment nets were used to hide the observer (Fig. 1) and other safety precautions were followed all through the monitoring process. Nikon P900, D7200, D500 fitted with a 200 $500 \mathrm{~mm}$ lens were used for photography purpose and Nikon AculonA211 (15x50) binocular for observing the nest.

Observations and discussion : Sailam village harbours a community-based 'Sailam Bird Sanctuary' where I. malayensis is a common sight to fly past above the forest. But the majestic slow and steady flights did not reveal the perch or the nest.

The breeding season of $I$. malayensis in Mizoram begins from mid-February and last till mid-March where aerial display and courtship act (Fig. 2) were visible. The first nest labelled as 1 was located before entering the village on $18^{\text {th }}$ February, 2018 as it was visible from the road connecting the village with Aizawl city. The second nest, labeled No. 2 (Fig. 3) was located downslope from the road on a large Castanopsis indica tree. The nest was placed in a more or less horizontal branch roughly $30 \mathrm{~m}$ above the ground. When female I. malayensis was sighted it was thought to 


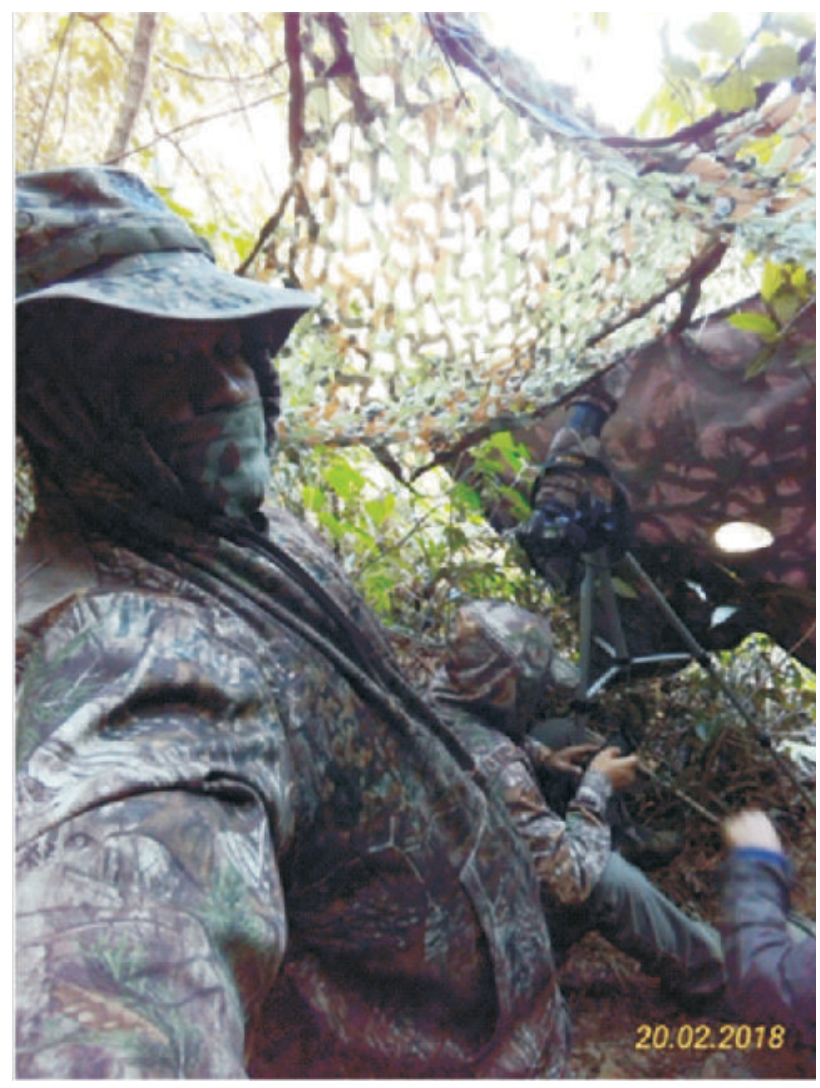

Fig. 1 : Observation post with camouflage net.

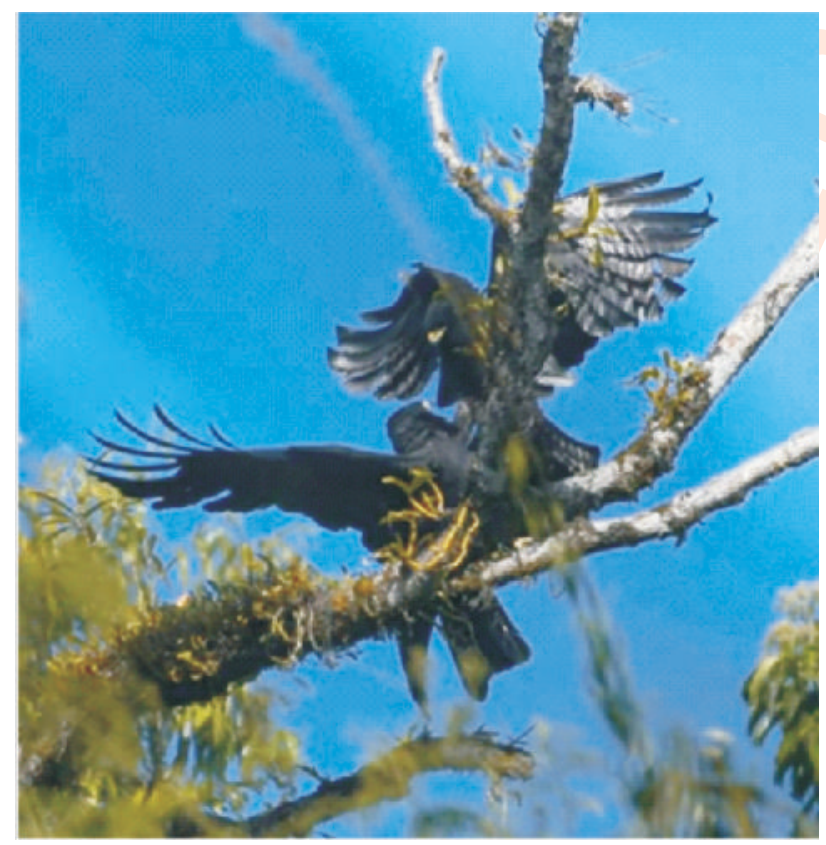

Fig. 2 : Courtship play/act of Ictinaetus malayensis.

be incubating the egg as it sits tightly the nest. This nest was observed occasionally due to the disturbances posed by the observer to the breeding pair as a result of poor cover to hide due to unfriendly terrain. The few observations done on this particular nest was to not reveal the nest to the passersby for the safety. Nest site selection was said to have an important consequence in the success of raptor nesting (Susanti et al., 2019).

The hatchlings first appeared on $7^{\text {th }}$ March, 2018 and then left the nest in mid-May. However, the young eagle that fledged was later found dead near the nest site by the villagers. The eagle was already decomposed and the frequent hailstone and thunderstorm prevailing in the area during that time was considered to be the cause of death. The observer recorded that the young eagle was fed with rodents alone and no other prey item was observed from this nest. The breeding pair was not very aggressive and usually abandoned the nest when disturbances like vehicle on the road, villagers passing by the area on foot, etc., occured in the vicinity.

The other nest of $I$. malayensis was traced by following the eagle carrying nesting materials- a dry branch followed by a green leafy twig. Nest 1 (Fig. 4) was located with the help of a local birdwatcher at the forest edge near the village at Hmunnuamkawng. The nest was built on a big branch of Castanopsis tribuloides (Ver. Thingsia), approximately $25 \mathrm{~m}$ above the ground, which was nearly horizontal with a good foliage cover on the sides and top. The nest was well concealed with two openings towards the north east and south west, although the nest is visible from the ground. The nest consisted of a large branch beneath with smaller branches lined with twig and green foliage.

The nest was first observed on $19^{\text {th }}$ February, 2018 while following the direction of flight of the eagle carrying a green leafy twig. The eagle was lost in the thickets of tall trees on the other side of the slope. The footpath usually used for bird watching as well as by the villagers for collecting firewood was followed. The nest was located roughly above the footpath however the tree was down the slope roughly $10 \mathrm{~m}$ from the footpath. The aggressive behavior displayed by both parents revealed the nest. The male and female hovers were close to the nest when we had reached the site. A good vantage point was located upslope, far enough not to distract the breeding pair for further monitoring of their behavior. In the year 2018, two active nests and two alternate nests were located. Both the active nest was monitored simultaneously. During early days of observation, the breeding pairs were most active in morning hours, usually 07:00 to 09:00 hrs. During this period, the pairs would hover above the nest, perch and playfully move around the branch and once a mating occured and the entire scene was photographed. The playful activity gradually subsided roughly after five days of observation. During the incubation period (after few days of observation), the female would sit firmly and usually did not leave the nest, even when human activity was observed on the footpath. Males usually visited the incubating female in the morning and afternoon, once with a food item. It was observed that the male would chase away 


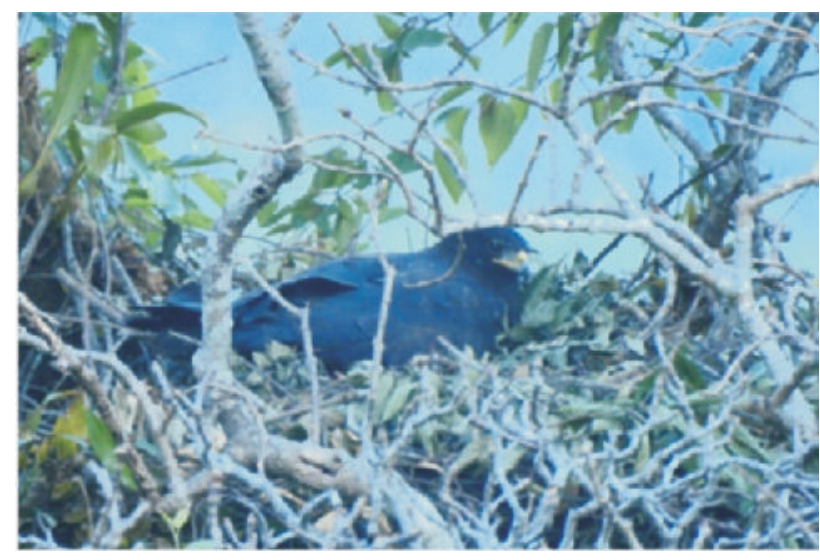

Fig. 3 : Nest No. 2 at Sailam village forest.

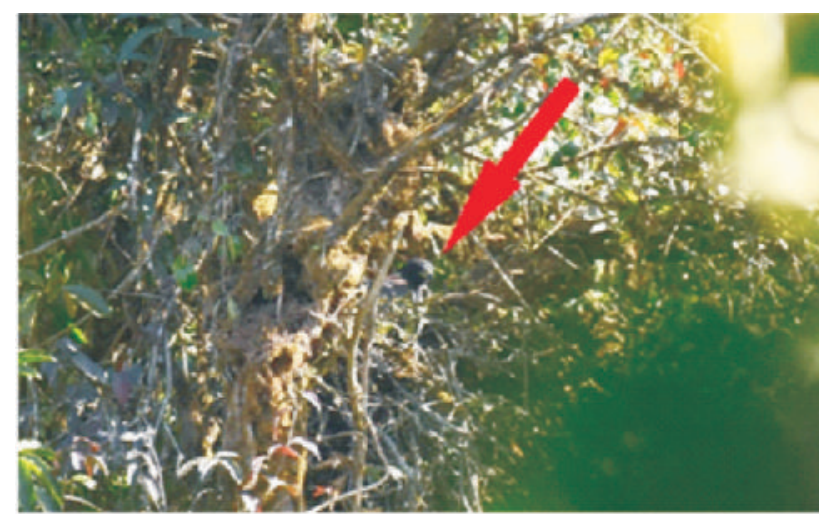

Fig. 4 : Nest No. 1 at Sailam village forest.

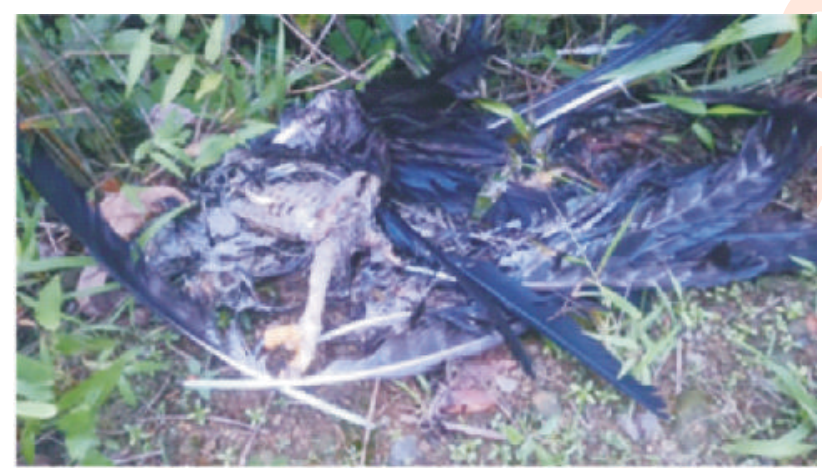

Fig. 5 : Carcass of young Ictinaetus malayensis.

another eagle if they flew over the nesting site with a screaming call while the female sat firmly on sits tightly in the nest. Smaller birds like Fire-breasted Flowerpecker, Nepal Fulvetta and Greyheaded Canary Flycatcher were often seen near the nest, but are were tolerated. The egg hatched on $1^{\text {st }}$ March, 2018 as the female sitting position of female changed slightly and there was a constant preening on the underside of its chest, suggesting that the eagle had already laid egg when the nest was first sighted. The incubation period was therefore assumed to be roughly 30 35 days. The eaglet/chick first appeared after 10 days of hatching as the female perched on the rim of the nest when the male entered the nest with the food item. It was observed that the nest was lined with green leafy twig more or less every alternate day. Apart from this, the nest was also lined with green leaves and new branches were added after few minutes of every feeding.

The observed diet mainly consisted of rodents viz., Pallas' Squirrel, Hoary-bellied Squirrel dominating the fed prey and unidentified rat species and rarely reptiles (1 lizard and 1 snake). Similar observations have been reported by Lin (2010) feeding on squirrels, on rats Samarawickrama (2011) and on giant flying squirrel (Lei et al., 2015). Birds, eggs and other diet items were not seen being fed to the eaglet during the observed days which coincides with the villagers saying that they never had observed I. malayensis (Indian Black Eagle, Lungdup) killing a village fowl. During study period, it was also observed that the parents consumed the leftover prey fed to the eaglet.

The young eagle was observed to perch on a branch near the nest for few days before finally leaving the nest and the nesting tree in the first week of May 2018. The last few weeks before the young eagle leaves the nest, no new foliage was found in the nest. The breeding season of I. malayensis in the state was thought to begin from late December to January or may continue as late as February, as the young eagle left the nest only in May.

The two nests monitored during the year 2018 were not reoccupied in the next breeding season which may be due to availability of other suitable trees near the vicinity as the $I$. malayensis was still a commoner in the area. Abandoning of previous nest sites may also be due to increased human activity like construction of roads (near nest No. 1) and other activities like collection of NTFPs. As stated earlier I. malayensis was primarily fed on rodents, thus controlling the population of rodents in the study area. Further, young eagle roughly required 50-60 days to be fully developed to leave the nest. The lengthy developmental stage makes young eaglets vulnerable to tribal hunters, who are opportunistic gatherers. The coincidence of the pre-monsoon thunderstorm accompanied by hailstone with the developing stage of young eagle may also pose serious consequences to the survival of eagle. The breeding success rate of the I. malayensis was quiet low as the nest we monitored had only $50 \%$ success rate with young eagle from Nest No.2 died few days after leaving the nest (Fig. 5).

\section{Acknowledgments}

We express our gratitude to the people of Sailam village, and members and leaders of the Sailam Ecological Conservation Society (S.E.C.S) for their care and support. We also convey our heartfelt gratitude to Pi Maruati, Pu Lalzawna Pachuau, Pu Lalrithanga, Pu Zokhuma and their families, and to all other people who have contributed to this study. 


\section{References}

Ali, S. and S.D. Ripley: Handbook of Birds of India and Pakistan. Vol. 4. Oxford University Press, Bombay (1983).

Borges, R.: Possible play between the Indian Giant Squirrel (Ratufa indica indica) and the Common Langur (Presbytis entellus). J. Bombay Nat. Hist. Soc., 83, 197 (1986).

Brazil, M.: Birds of EastAsia. London: Christopher Helm (2009).

Chiu, S.C. and K.C Lim: The first breeding record of the Black Eagle Ictinaetus malayensis in Malaysia. Suara Enggang., 11, 14-16 (2003).

Clark, W.S.: Species account: Indian Black Eagle. In: Handbook of the Birds of the World, 2. (Eds.: J. del Hoyo, A. Elliott and J. Sargatal). Barcelona: Lynx Editions, p.192 (1994).

Ferguson-Lees, J. and D.A. Christie: Raptors of the world. London: Christopher Helm (2001).

Fernando, R.H.S.S., A. Palihawadana and S. Gunasekara: First site record of a Black Eagle Ictinaetus malayensis nest in Sri Lanka. Sri Lanka Naturalist, 4, 49 (2001).

Henry, G.M.: Flight of the Black Eagle Ictinaetus malayensis perniger, Hodg. Nature, 132, 516-517 (1933).

Lalthanzara, H., R. Kasambe and L. Sailo: Himalayan Vulture: Sighting report and people's perception in Mizoram. Mistnet, 16,10-11 (2015).

Lei, Z., Y. Xiao-Nong, H. Guang, L. Tian-Tian, D. Zi-Yue and S. Yue-Hua: Notes on the diet of the Black Eagle Ictinaetus malayensis. BirdingASIA, 23, 100-101(2015).

Lepage, D.: Bird Life International; Species fact sheet: Ictinaetus malayensis. Downloaded from http://www.birdlife.org on 26/06/2014 (2014).

Lim, W.S. and T.S.S. Hut: Observation of Black Eagle Ictinaetus malayensis in Plawangan-Turgo Nature Reserve, Gunung Merapi mountain, Indonesia. In: Proceedings of $4^{\text {th }}$ Symposium on Asian Raptors (Eds.: J. Abu, M.H.N. Chong, A.C. Sebastian and Y.C. Aik). Kuala Lumpur: Committee for $4^{\text {th }}$ Symposium on Asian Raptors. pp.48-56 (2005).

Lin, W.H.: Habitat use and breeding ecology of Black Eagle Ictinaetus malayensis in northern Taiwan. In: Proceedings of $4^{\text {th }}$ symposium on Asian Raptors 2005. (Eds.: J. Abu, M.H.N. Chong, A. C. Sebastian and Y.C. Aik). Kuala Lumpur: Committee for $4^{\text {th }}$ Symposium on Asian Raptors. pp.35-41 (2005).

Lin W.H. and W.C. Lin: Diet survey of the Indian Black Eagle during the breeding season: A case study in northeast Taiwan. In: The $4^{\text {th }}$ Symposium on Ecology of Raptors in Taiwan. (Eds.: L.L. Severinghaus and S.M. Lin): Program and Abstracts. Taipei: Raptor Research Group of Taiwan, p.13 (2010).

Naoroji, R.: Birds of prey of the Indian subcontinent. London: Christopher Helm (2006).

Rasmussen, P.C. and J.C. Anderton: Birds of South Asia: The Ripley guide. $2^{\text {nd }}$ Edn., Washington DC, Michigan and Barcelona: Smithsonian Institution, Michigan State University \& Lynx Editions (2012).

Robert, T.J.: The Birds of Pakistan. Vol. 1, Non-Passeriformes. Oxford University Press. Delhi (1991).

Sailo, L., R. Kasambe and H. Lalthanzara: Bird survey in Lengteng Wildlife Sanctuary and Blue Mountain (Phawngpui) National Park, Mizoram. Buceros, 18, 6-13 (2013).

Samarawickrama, P., K. Ariyasiri, U. Menike, N. Samarasingha and M. Meegaskumbura: Observations of Black Eagle (Ictinaetus malayensis) nesting in Sri Lanka. Tiger paper, 38, 1-4 (2011).

Soleha, D.: Reproductive behavior of Black Eagle (Ictinaetus malayensis) in the southern slope of Mount Merapi, Yogyakarta. In: Proceedings Asian Raptor Research Conservation: The $2^{\text {nd }}$ Symposium on Raptors of Asia, Grand Aquila, Indonesia, 25-27 July 2000. (Ed.: D. Prawiradilaga). Indonesian Committee for the Second Symposium of Asian Raptor Research and Conservation, Cibinong, Indonesia, p. 208 (2000).

Stresemann, E. and D. Amadon: Ictinaetus malayensis. In: Check-list of birds of the world, 1. (Eds.: E. Mayr and G. W. Cottrell). Second Edition. Cambridge, Mass. Museum of Comparative Zoology, $p$. 378 (1979).

Susanti, W., Parikesit, I. Johan and M.P. Dewi: Conservation and management strategies for the sustainability of raptors in a human-modified landscape. Intl. J. Cons. Sci., 10, 749-762 (2019). 